University of Wollongong

Research Online

Sydney Business School - Papers

Faculty of Business

$1-1-2019$

\title{
Understanding supply chain analytics capabilities and agility for data-rich environments
}

Samuel Fosso Wamba

Toulouse Business School, samuel.fosso.wamba@neoma-bs.fr

Shahriar Akter

University of Wollongong, sakter@uow.edu.au

Follow this and additional works at: https://ro.uow.edu.au/gsbpapers

Part of the Business Commons

\section{Recommended Citation}

Fosso Wamba, Samuel and Akter, Shahriar: Understanding supply chain analytics capabilities and agility for data-rich environments 2019, 1-26.

https://ro.uow.edu.au/gsbpapers/581

Research Online is the open access institutional repository for the University of Wollongong. For further information contact the UOW Library: research-pubs@uow.edu.au 


\title{
Understanding supply chain analytics capabilities and agility for data-rich environments
}

\begin{abstract}
Purpose: Big data-driven supply chain analytics capability (SCAC) is now emerging as the next frontier of supply chain transformation. Yet, very few studies have been directed to identify its dimensions, subdimensions and model their holistic impact on supply chain agility (SCAG) and firm performance (FPER). Therefore, to fill this gap, the purpose of this paper is to develop and validate a dynamic SCAC model and assess both its direct and indirect impact on FPER using analytics-driven SCAG as a mediator.

Design/methodology/approach: The study draws on the emerging literature on big data, the resourcebased view and the dynamic capability theory to develop a multi-dimensional, hierarchical SCAC model. Then, the model is tested using data collected from supply chain analytics professionals, managers and mid-level manager in the USA. The study uses the partial least squares-based structural equation modeling to prove the research model.

Findings: The findings of the study identify supply chain management (i.e. planning, investment, coordination and control), supply chain technology (i.e. connectivity, compatibility and modularity) and supply chain talent (i.e. technology management knowledge, technical knowledge, relational knowledge and business knowledge) as the significant antecedents of a dynamic SCAC model. The study also identifies analytics-driven SCAG as the significant mediator between overall SCAC and FPER. Based on these key findings, the paper discusses their implications for theory, methods and practice. Finally, limitations and future research directions are presented.
\end{abstract}

Originality/value: The study fills an important gap in supply chain management research by estimating the significance of various dimensions and subdimensions of a dynamic SCAC model and their overall effects on SCAG and FPER.

\section{Disciplines}

Business

\section{Publication Details}

Fosso Wamba, S. \& Akter, S. (2019). Understanding supply chain analytics capabilities and agility for datarich environments. International Journal of Operations and Production Management, 39 (6/7/8), 887-912. 


\title{
Understanding Supply Chain Analytics Capabilities and Agility for Data- Rich Environments
}

\author{
Samuel Fosso Wamba \& Shahriar Akter
}

\begin{abstract}
Purpose: Big data-driven supply chain analytics capability is now emerging as the next frontier of supply chain transformation. Yet, very few studies have been directed to identify its dimensions, subdimensions and model their holistic impact on supply chain agility and firm performance. Therefore, to fill this gap, this study develops and validates a dynamic supply chain analytics capability model and assesses both its direct and indirect impact on firm performance using analytics-driven supply chain agility as a mediator.
\end{abstract}

Design/methodology/approach (mandatory): The study draws on the emerging literature on big data, the resource-based view (RBV) and the dynamic capability theory (DCT) to develop a multi-dimensional, hierarchical supply chain analytics capability model. Then, the model is tested using data collected from supply chain analytics professionals, managers and mid-level manager in the U.S. The study uses the partial least squares-based structural equation modelling (PLS-SEM) to prove the research model.

Findings (mandatory): The findings of the study identify supply chain management (i.e., planning, investment, coordination \& control), supply chain technology (i.e., connectivity, compatibility \& modularity) and supply chain talent (i.e., technology management knowledge, technical knowledge, relational knowledge and business knowledge) as the significant antecedents of a dynamic supply chain analytics capability model. The study also identifies analytics-driven supply chain agility as the significant mediator between overall supply chain analytics capability and firm performance. Based on these key findings, the paper discusses their implications for theory, methods and practice. Finally, limitations and future research directions are presented.

Originality/value (mandatory) : The study fills an important gap in supply chain management research by estimating the significance of various dimensions and subdimensions of a dynamic supply chain analytics capability model and their overall effects on supply chain agility and firm performance.

Keywords: Big data, supply chain analytics capability, RBV, dynamic capability, supply chain agility, firm performance. 


\section{INTRODUCTION}

Big data analytics (BDA) is defined as "a holistic process that involves 5V (volume, velocity, variety, value, and veracity) in terms of collection, analysis, use, and interpretation of data for various functional divisions, with a view to gaining actionable insights, creating business value, and establishing competitive advantages” (p. 235) (Fosso Wamba, Akter et al. 2015). BDA is considered as "an end-all solution to supply chain problems" (p. 1) (Lopez 2017) or “a revolution that will transform supply chain design and management” (p. 77) (Waller and Fawcett 2013), or even the "silver bullet for supply-chain forecasting” (p. 10) (Snapp 2017). The high potential of big data-driven supply chain analytics capability (SCAC) (Tiwari, Wee et al. 2018) for business value has positioned it as an important game-changer in the supply chain and one of the "hottest topics" among supply chain managers (Tay 2016). The objective of using BDA across all supply chain processes is to improve supply chain analytics capability (SCAC). As such, SCAC is assumed to improve supply chain agility (SCAG) by synchronizing demand and supply (Niu and Zou 2017) and by enhancing the overall business value and performance (Gunasekaran, Papadopoulos et al. 2017, Hofmann 2017, Brinch 2018). Recent industry literature shows that the market of supply chain analytics is expected to grow from about $\$ 4.8$ billion 2019 (Newswire 2015) to reach about $\$ 9.87$ billion by 2025 (Newswire 2017), thus growing potentially by $13.68 \%$ during the period $2017-2021$ (Newswire 2017).

Although supply chain analytics is gaining momentum in the emerging big data economy, the steep growth curve of performance using analytics is flattening out for many companies (Kiron, Prentice et al. 2014). A group of scholars have been persistently arguing that the investment in data-driven supply chain analytics and performance is a myth. The present study attempts to respond to this by providing an empirical evidence on how SCAC influences supply chain agility (SCAG) and firm performance (FPER) (Manyika, Chui et al. 
2011, Ransbotham, Kiron et al. 2016, Dubey, Altay et al. 2018). It also seeks to examine the dimensions of SCAC in a big data environment and to model their overall effects on SCAG and FPER. Drawing on the resource-based view (RBV) and the dynamic capability theory (DCT), this study proposes management, technology and talent capabilities as the building blocks of SCAC to enhance SCAG and FPER. For example, Bowers et al. (2017) present the conceptual case of a U.S.-based manufacturer and marketer of basic apparels that is using SCAC to enhance supply chain responsiveness. Lail and Richardson (2015) argue that SCAC could improve end-to-end supply chain productivity, while Orenstein et al. (2016) report that "if the supply chain data streams from multiple logistics providers would be integrated, this could eliminate current market fragmentation, enabling powerful new collaboration and services” (p. 36). McCrea (2017)demonstrates that SCAC could enhance supply chain agility by providing better diagnostic information, sensing external factors, forecasting robust demands, controlling variability in demand and cycle times, and preparing for the social media, news, event and weather data waves. Despite various anecdotal and fragmented success stories, the components of big data-driven SCAC are still not well explored as well as their overall effects on SCAG and FPER (e.g., Ashrafi et al. 2019, Dubey et al. 2018, Giannakis and Louis, 2016). Also, the existing SCAC-SCAG-FPER relationship lacks strong theoretical grounding and empirical evidence. Thus, the following research questions are expected to be addressed here:

- What are the core components of SCAC in the big data environment?

- What is the impact of the overall SCAC on SCAG?

- Does SCAG mediate the relationship between SCAC and firm performance?

To address these research questions, this study draws on the emerging literature on BDA, RBV and DCT to develop and test our proposed research model. The core of the paper starts with a presentation of the theoretical background, followed by the research method and an 
analysis of data and findings. The paper ends with the discussion of results and a review of a number of implications.

\section{LITERATURE REVIEW AND THEORIES}

\section{Theories: the resource-based view (RBV) and dynamic capability theory (DCT)}

The resource-based view was developed and proposed by (Barney 1991) as a strategic tool to understand how to create and sustain competitive advantage. RBV argues that the differences between competing firms in a given market arise from each firm's unique capacity to identify and build a bundle of valuable, rare, inimitable and non-substitutable resources (e.g., assets, capabilities, organizational processes, firm attributes, information, knowledge) to create business value (Barney 2001, Hoopes, Madsen et al. 2003) and achieve sustainable competitive advantage (Barney 1991). While RBV has been considered as an important strategic tool in supply chain management, it has also generated a lot of criticisms. For example, Priem and Butler (2001) argue that the RVB is not "currently a theoretical structure" (p. 22), though they recognized that the RBV has assumed "stability in product markets and eschewed determining resources' values” (p. 22). In another paper (2001), the same authors went as far as suggesting that there is a "tautology in the RBV" (p. 57). It should be noted that various authors successfully used the RBV (Ellinger, Natarajarathinam et al. 2011, Chae, Olson et al. 2014, Gligor 2014, Khanchanapong, Prajogo et al. 2014, Gligor, Esmark et al. 2015, Hitt, Xu et al. 2016, Han, Wang et al. 2017) and DCT (Gligor, Esmark et al. 2015, Han, Wang et al. 2017). Some of them, including Chae et al. (2014), went further by demonstrating the potential of analytics to play the role of a distinctive resource for improving the performance of manufacturing plants. Others (e.g., Han et al. (2017)) reported how this technology can efficiently enhance performance in any industry. Dubey, Gunasekaran et al. 
(2019) saw in data analytics capability a unique building block for information processing capacity and supply chain resilience.

While RBV is proved to be useful in identifying valuable resources for SCAC, much light is yet to be shed on how to adapt resources such as talent/technology/management capability in a fast-changing big data environment. The theory about dynamic capability has emerged to address some of the issues raised about the RBV. Teece et al. (1997) have extended the RBV to develop the dynamic capability theory (DCT). The DCT helps orgnizations to assess the source of business value creation and to capture competitive advantage in volatile markets and changing environments (Winter 2003, Rothaermel and Hess 2007, Teece 2012, Eckstein, Goellner et al. 2015). The DCT argues that the realization of a sustained competitive advantage by a firm depends on its ability to integrate, build, and reconfigure its internal and external resources and competencies to better adapt in environmental turbulence (Teece and Pisano 1994, Teece, Pisano et al. 1997). Scholars suggest that organizations that can make good use of DC could achieve long-term competitive advantage (Augier and Teece 2009) (Cavusgil, Seggie et al. 2007, Augier and Teece 2009). In an industry where change is too frequent, dynamic analytics capabilities such as supply chain agility, supply chain adaptability (Blome, Schoenherr et al. 2013, Eckstein, Goellner et al. 2015, Rameshwar, Nezih et al. 2018) and supply chain visibility (Rameshwar, Nezih et al. 2018) can help firms and supply chain members to integrate, build, and reconfigure strategic resources and capabilities to accelerate firm performance. We draw from these prior studies and argue that SCAC and SCAG are complementary dynamic capabilities that could lead to sustainable competitive advantage. For example, SCAC can establish agility and enhance performance by means of data-driven insights regarding operations (Teece 2014). 


\section{Supply Chain Analytics Capabilities as Dynamic Capabilities: Dimensions and Effects}

Dynamic capabilities are defined as higher-order capabilities that organise resources to enhance the performance of an organisation in changing contexts (Teece 2014). The building blocks of the DC theory is appropriate for supply chain analytics as it leverages management, technology and talent capabilities to improve organizational agility (Akter, Wamba et al. 2016). Drawing on the DC theory, we define SCAC as a holistic analytics process that provides robust insights for real-time decision-making using various technological, managerial and personnel capabilities. Such an analytics platform utilizes sensor data, RFID data, location data through mobile devices, click-stream data (e.g., web and online advertisements, tweets, blogs, Facebook wall postings), transaction data, video data, voice data and consumer sentiments from social media to reinforce insights and decision-making (Wamba, Gunasekaran et al. 2017). For example, Roßmann et al. (2017) demonstrate the role of analytics technology to enhance demand forecasts, reduce safety stocks and improve the management of supplier performance. Similarly, Zhao et al. (2017) highlight analytics talent capability as a conducive means of developing an optimization model for the robust supply chain management. In a similar spirit, scholars indicate how it is urgent to embrace analytics management capability so as to improve supply chain efficiency (Gheorghe, Massimo et al. 2015), develop compensation strategies in large-scale data breaches (Kude, Hoehle et al. 2017) and mediate the risk of default of trade credit in the supply chain (Tsao 2017).

SCAG is defined as "a firm's ability to perform operational activities together with channel partners in order to adapt or respond to marketplace changes in a rapid manner” (p. 1453) (Liu et al., 2013). Lee (2004) discovered that SCAC creates SCAG to balance between demand and supply. Aslam et al. (2018), on their part, better explained the role of SCAC in 
developing an agile and ambidextrous supply chain. To Ketchen and Hult (2007), SCAC and SCAG are complementary dynamic capabilities that result in superior firm performance. According to Peteraf and Barney (2003), firm performance is reflected in the creation of more economic value than the marginal competitor in the supply chain industry. Overall, supply chain management firms are keen to develop analytics capabilities that can adapt to, orchestrate and innovate in changing markets (Teece 2014). Although the components of SCAC have been identified under various dimensions, the extent literature identifies three overarching themes: SCAC management capability, SCAC technology capability, and SCAC talent capability. 
Table 1: Typologies of Supply Chain Analytics Capabilities

\begin{tabular}{|c|c|c|c|}
\hline \multirow[t]{2}{*}{ Related studies } & \multicolumn{3}{|c|}{ Typologies } \\
\hline & Supply chain management capability & Supply chain technology capability & Supply chain talent capability \\
\hline $\begin{array}{l}\text { Dubey, } \\
\text { Gunasekaran et al. } \\
\text { (2019) }\end{array}$ & Big data-driven culture & Tangible resources & Human skills \\
\hline $\begin{array}{l}\text { Mikalef, Boura et } \\
\text { al. (2019) }\end{array}$ & $\begin{array}{l}\text { Data driven culture, organizational } \\
\text { learning }\end{array}$ & Data and infrastructure & Technical skills, managerial skills \\
\hline $\begin{array}{l}\text { Kiron, Prentice et } \\
\text { al. (2014) }\end{array}$ & $\begin{array}{l}\text { Management (planning options, } \\
\text { coordination between analytical producers } \\
\text { and managers, model-based decisions and } \\
\text { control) }\end{array}$ & $\begin{array}{l}\text { Infrastructure and processes (machine } \\
\text { learning, data management and } \\
\text { information systems) to improve data } \\
\text { quality. }\end{array}$ & $\begin{array}{l}\text { Talent (e.g., domain knowledge, statistics } \\
\text { and other technical skills). }\end{array}$ \\
\hline $\begin{array}{l}\text { Akter, Wamba et al. } \\
\text { (2016) }\end{array}$ & $\begin{array}{l}\text { Big data management capability in terms } \\
\text { of planning, investment, etc. }\end{array}$ & $\begin{array}{l}\text { Big data technology capability in terms of } \\
\text { data integration, privacy, etc. }\end{array}$ & $\begin{array}{l}\text { Big data personnel capability in terms of } \\
\text { business and technical skills. }\end{array}$ \\
\hline $\begin{array}{l}\text { McAfee and } \\
\text { Brynjolfsson (2012) }\end{array}$ & Strategic planning and corporate culture & Infrastructure & Capabilities of big data scientists \\
\hline $\begin{array}{l}\text { Gunasekaran, } \\
\text { Papadopoulos et al. } \\
(2017)\end{array}$ & Top management commitment & Connectivity and information sharing & Technical and business knowledge \\
\hline $\begin{array}{l}\text { Barton and Court } \\
\text { (2012) }\end{array}$ & Organisational planning & Technology and data resources & $\begin{array}{l}\text { Personnel capability to develop } \\
\text { descriptive, predictive and prescriptive } \\
\text { models }\end{array}$ \\
\hline $\begin{array}{l}\text { McAfee and } \\
\text { Brynjolfsson (2012) }\end{array}$ & Corporate strategy & IT infrastructure & Skills and knowledge of data scientists \\
\hline $\begin{array}{l}\text { Ransbotham, Kiron } \\
\text { et al. (2015) }\end{array}$ & $\begin{array}{l}\text { Analytics planning, sharing and } \\
\text { coordination, investment, control on } \\
\text { analytics as a whole. }\end{array}$ & $\begin{array}{l}\text { Organizational openness, compatibility } \\
\text { analytics technology, collaborative use of } \\
\text { data (connectivity). }\end{array}$ & $\begin{array}{l}\text { Analytical talent, technical and business } \\
\text { knowledge, organization as a whole } \\
\text { effective in disseminating insights. }\end{array}$ \\
\hline
\end{tabular}




\section{Research Model and Hypotheses Development}

The proposed model (see Figure 1) is based on the frequently cited dimensions in the analytics literature (see Table 1) and on pertinent theoretical foundations (i.e., RBV and DCT) that impact supply chain analytics capability. The review of big data literature and the theoretical exploration of the study showed that SCAC was repeatedly identified as a multidimensional, hierarchical construct with various subdimensions determining the primary dimensions. As such, we propose SCAC model as a third-order construct that also has three second-order dimensions (supply chain management capability, supply chain technology capability, and supply chain talent capability). By doing so, we contribute to extending this stream of research in the supply chain context. Indeed, this unique configuration of SCAC could allow firm and supply chain members to create business value and achieve sustainable competitive advantage (Figure 1). Therefore, we propose that SCAC will have a significant positive impact on FPER through SCAG.

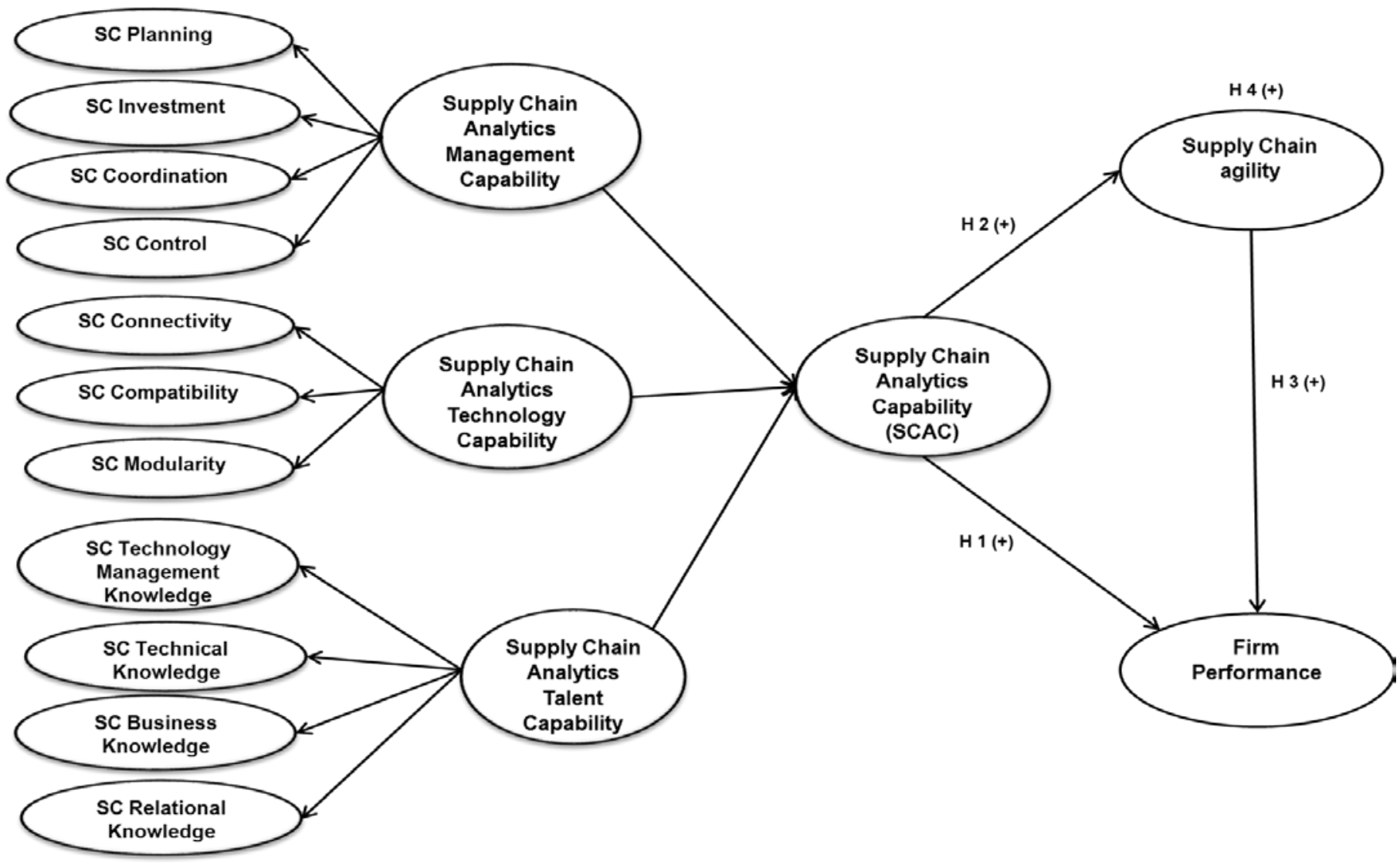

Figure 1: Proposed Research Model 
SCAG is now considered a key enabler of supply chain success in an extremely turbulent and fluctuating economic context (I. van Hoek, Harrison et al. 2001, Sharifi, Ismail et al. 2006, Sharifi, Ismail et al. 2009, Najafi Tavani, Sharifi et al. 2013, Cerruti, Mena et al. 2016) that seeks to create business value and sustain a particular competitive advantage (Ngai, Chau et al. 2011). For example, (Dwayne Whitten, Green et al. 2012) argued that the success of supply chain members requires an agile supply chain environment. (p. 30). As an operational (Liu, Ke et al. 2013, Yang 2014) and relational capability (Yang 2014), agility allows firms not only to quickly respond to customer requests and market changes (I. van Hoek, Harrison et al. 2001), but also to face market uncertainty (Sharifi, Ismail et al. 2006, Chiang, Kocabasoglu-Hillmer et al. 2012), foster supply chain collaboration (Dwayne Whitten, Green et al. 2012) and achieve time-to-market (Cerruti, Mena et al. 2016). It also enhances product customization, delivery performance, and products development time (Swafford, Ghosh et al. 2008), while speeding access to new business opportunities (Sharifi, Ismail et al. 2006). Given the magnitude of all these capabilities, some scholars have even suggested that SCAG could "act as a rare, valuable, and imperfectly imitable operational capability, which is critical to improving firm performance” (p. 1453) (Liu, Ke et al. 2013).

A key driver of firm and SCAG is IT (Zhang and Sharifi 2000). For example, IT capability is a strong predictor of SCAG (Yang 2014) and can significantly improve the supply chain’s ability to respond to market changes (DeGroote and Marx 2013), notably by reinforcing adequacy, accuracy, accessibility, and the timeliness of information flow between supply chain members. In addition, IT capability has a direct positive impact on SCAG, which in turn has a positive effect on performance (Yang 2014). (Chan, Ngai et al. 2017) showed that SCAG plays an important role in mediating the effects of both strategic and manufacturing flexibilities on firm performance” (p. 486). (Liu, Ke et al. 2013) demonstrated that IT 
capability has a positive impact on firm performance through SCAG and its absorptive capacity. On their part, (Swafford, Ghosh et al. 2008) showed that IT integration positively influences SCAG, which in turn, has a positive effect on competitive business performance.

In this study, we suggest that analytics-driven SCAG is a dynamic capability (Gligor and Holcomb 2012) that will mediate the relationship between SCAC and firm performance. Early studies (Sanders and Premus 2005, Lin 2007, Kim, Shin et al. 2011, Chen, Wang et al. 2014) and the emerging literature on BDA capability (Akter, Fosso Wamba et al. 2016, Fosso Wamba, Gunasekaran et al. 2017) have established a significant positive relationship between investment in supply chain analytics capability and organizational outcomes. (Dubey, Gunasekaran et al. 2019) showed that BDA capability is an important facilitator of improved information-processing capacity and supply chain resilience, the objective of which is to reduce a ripple effect in supply chains or to rapidly recover from supply chain disruptions. SCAC could provide timely and accurate information about the spending patterns developed by firms to support strategic sourcing decisions (Tiwari, Wee et al. 2018). Moreover, SCAC allows end-to-end real-time information sharing as well as the monitoring of supply chain activities that could lead to improved supply chain decisions (Tiwari, Wee et al. 2018), and thus to enhanced SCAG (Giannakis and Louis 2016, Tiwari, Wee et al. 2018) and firm performance (Dubey, Gunasekaran et al. 2019). Based on this discussion, we propose the following hypotheses:

H1: Supply chain analytics capability has a significant positive impact on firm performance.

H2: Supply chain analytics capability has a significant positive impact on SCAG. 
In a similar spirit, the extant literature on supply chain management has found a significant link between SCAG and performance (see, Swafford et al. 2006, 2008; Whitten et al. 2012; Gligor et al. 2015; Eckstein et al. 2015; Dubey et al. 2018a,b). For instance, Srinivasan and Swink (2018) have highlighted the role of SCAG in cost reduction, while Ayinder et al. (2019) explored the exponential growth of supply chain performance through SCAG. Gligor and Holcomb (2012) (p. 299) argue that SCAG could fooster operating routines modification, facilitate organizational resource reconfiguration, and improve organizational sensing ability. Eckstein et al. (2015) revealed that SCAG plays a critical role in balancing supply and demand, reducing the cost of inventory and transportation. By exploiting the agility of their supply chains, firms can enhance their own performance as throughput and set-up times will be improved, the replacement times of materials and services shortened, and the production processes quickly adjusted in order to customise products cost-efficiently while avoiding product markdowns caused by excess inventory (Lee, 2004). Indeed, SCAG enables organizational capabilities to achieve improved firm performance and sustained competitive advantage. Similarly, it is an important driver of organizational logistics performance (Dubey, Singh et al. 2015). Based on this discussion, we hypothesize that:

\section{H3: SCAG has a significant positive impact on firm performance in the context of BDA environment.}

Supply chain agility can improve firm performance through the mediating role of other dynamic capabilities (Eckstein et al. 2015; Dubey et al. 2018a,b). SCAG depends on SCAC to implement and leverage the subdimensions of various analytics capabilities. Fosso Wamba et al. (2017) highlighted the dynamic capability of SCAG to sense, seize and transform supply chain processes in order to synchronize demand and supply. According to the extant research on supply chain management, a high level of SCAC can strengthen firms' core characteristics 
such as ambidexterity, adaptability and swiftness (Gunasekaran, Papadopoulos et al. 2017, Hofmann 2017, Brinch 2018). Therefore, firms can upgrade their performance in terms of sales, profit and return on investment if their supply chain processes are robust. Thus, we hypothesize that SCAG, as a strategic dynamic capability, will mediate the relationship between SCAC and FPER.

H4: SCAG mediates the relationship between supply chain analytics capability and firm performance.

\section{RESEARCH METHODOLOGY}

This study used a web-based survey to collect data from supply chain professionals, managers and mid-level managers in the USA. The survey was realized by a market research firm with more than 11 million panellists across 40 countries. Our study was mainly interested by supply chain professionals and managers in the U.S. with at least 3 years' experience in supply chain analytics. More precisely, an invitation explaining the objectives of the study was sent to the targeted panellists in 2017, including supply chain executives in charge of activities such as logistics, procurement, supply chain planning, purchasing, transportation, warehousing, production or shipping. A total of 679 persons from among those contacted agreed to participate in the study. At the end of the data collection process, we received 281 completed questionnaires or a response rate of $41 \%$. Prior to the final data collection, a survey pre-testing was realized with 7 scholars working on BDA-related projects.

All the constructs used in the study were derived from prior studies and adapted to fit our research context of BDA in the supply chain context. Using a seven-point Likert scale ranging from "strongly disagree” (1) to "strongly agree” (7), the items were measured. Data analysis was realized using a partial least squares structural equation modelling (PLS-SEM) tool called SmartPLS 3.0 (Ringle, Wende et al. 2014). Appendix 1 describes all the scales and items. 


\section{Analysis and Findings}

Based on the established guidelines on model development (Chin 2010, Ringle, Sarstedt et al. 2012), we identify that the mode of measurement as reflective-formative as the first and second-order dimensions are reflective (Mode A) but the third-order dimensions are formative (Mode B). The study applies partial least squares (PLS) path modelling to establish more theoretical parsimony and less model complexity (Wetzels, Odekerken-Schroder et al. 2009). Specifically, it applies PLS to avoid the limitations regarding sample size and distributional properties (Hair, Ringle et al. 2011). The study used SmartPLS 3.0 (Ringle, Wende et al. 2014) nonparametric bootstrapping (Efron and Tibshirani 1993, Chin 1998, Tenenhaus, Vinzi et al. 2005) with 5,000 replications. The study estimated the model for the inside approximation using a path weighting scheme (Hair Jr, Hult et al. 2013). Following the procedures of higher-order modeling (Becker, Beverungen et al. 2010, Chin 2010), the study repeatedly used indicators at first-order and second-order levels to estimate the score of the third-order construct. Therefore, the highest-order SCAC construct consists of all the items of the corresponding first-order latent constructs.

\section{Measurement Model}

The study confirms the convergent and discriminant validity of the first-order measurement model using PLS path modelling (Table 2). The 11 supply chain analytics subdimensions which represent the first-order model are encapsulated under three second-order dimensions: supply chain management capability, supply chain technology capability and supply chain talent capability. First, the measurement model results show that items loadings are significant at $\mathrm{p}<0.001$ and all they exceed 0.7 threshold value. Second, the study calculated average variance extracted (AVE) to measure the amount of variance and composite reliability (CR) to 
measure internal consistency (Fornell and Larcker 1981, Chin 1998) that indicates the reliability of all the measurement scales.

Both CRs and AVEs of all scales are either equal to or exceed 0.80 and 0.50 cut-off values, respectively (Fornell and Larcker 1981, Hair, Hult et al. 2013), which confirms corresponding reliability and convergent validity of first-order constructs (Fornell and Larcker 1981). The study also confirmed that the weights of formative items are significant at $\mathrm{p}<0.01$ and the variance inflation factor (VIF) is less than the cut-off value of 5. Thus, the findings of the measurement model confirm adequate reliability and validity for all the constructs .

Table 3 shows the correlation matrix reporting the $\sqrt{A V E}$ in the diagonals, which shows adequate discriminant validity as it exceeds inter-correlation with other LVs in the first-order model (Fornell and Larcker 1981, Chin 1998, Chin 2010). This also indicates that constructs conceptually different from each other (Chin 2010). Further discriminant validity was confirmed by assessing the cross-loadings, which reflects constructs with a strong correlation with their own items than others (Fornell and Bookstein 1982, Chin 1998). Overall, the evidence of adequate reliability (AVE $>0.50, \mathrm{CR}>0.80$ ), convergent validity (loadings $>$ 0.80 ), and discriminant validity $(\sqrt{A V E}>$ correlations) demonstrates the robustness of the first-order measurement model. As a result, the measurement model was considered satisfactory and employed for testing the higher-order measurement model and the structural model in the next sections. 
Table 2: Assessment of First-Order, Reflective Model

\begin{tabular}{|c|c|c|c|c|}
\hline Reflective Constructs & Items & Loadings & CR & AVE \\
\hline $\begin{array}{l}\text { Big data-based supply chain } \\
\text { planning } \\
\text { (SCPL) }\end{array}$ & $\begin{array}{l}\text { SCPL1 } \\
\text { SCPL2 } \\
\text { SCPL3 } \\
\text { SCPL4 }\end{array}$ & $\begin{array}{l}0.914 \\
0.930 \\
0.931 \\
0.900\end{array}$ & 0.955 & 0.844 \\
\hline $\begin{array}{l}\text { Big data-based supply chain } \\
\text { investment decision making } \\
\text { (SCID) }\end{array}$ & $\begin{array}{l}\text { SCID1 } \\
\text { SCID2 } \\
\text { SCID3 } \\
\text { SCID4 }\end{array}$ & $\begin{array}{l}0.900 \\
0.884 \\
0.913 \\
0.915\end{array}$ & 0.946 & 0.815 \\
\hline $\begin{array}{l}\text { Big data-based supply chain } \\
\text { coordination } \\
\text { (SCCO) }\end{array}$ & $\begin{array}{l}\text { SCCO1 } \\
\text { SCCO2 } \\
\text { SCCO3 } \\
\text { SCCO4 }\end{array}$ & $\begin{array}{l}0.889 \\
0.908 \\
0.902 \\
0.892\end{array}$ & 0.943 & 0.806 \\
\hline $\begin{array}{l}\text { Big data-based supply chain control } \\
\text { (SCCT) }\end{array}$ & $\begin{array}{l}\text { SCCT1 } \\
\text { SCCT2 } \\
\text { SCCT3 } \\
\text { SCCT4 }\end{array}$ & $\begin{array}{l}0.914 \\
0.920 \\
0.912 \\
0.900\end{array}$ & 0.951 & 0.830 \\
\hline $\begin{array}{l}\text { Big data-based supply chain } \\
\text { connectivity } \\
(\mathrm{SCCN})\end{array}$ & $\begin{array}{l}\text { SCCN1 } \\
\text { SCCN2 } \\
\text { SCCN3 } \\
\text { SCCN4 }\end{array}$ & $\begin{array}{l}0.917 \\
0.900 \\
0.905 \\
0.853\end{array}$ & 0.940 & 0.799 \\
\hline $\begin{array}{l}\text { Big data-based supply chain } \\
\text { compatibility } \\
\text { (SCCM) }\end{array}$ & $\begin{array}{l}\text { SCCM1 } \\
\text { SCCM2 } \\
\text { SCCM3 } \\
\text { SCCM4 }\end{array}$ & $\begin{array}{l}0.902 \\
0.931 \\
0.923 \\
0.883\end{array}$ & 0.951 & 0.828 \\
\hline $\begin{array}{l}\text { Big data based supply chain } \\
\text { modularity } \\
\text { (SCMD) }\end{array}$ & $\begin{array}{l}\text { SCMD1 } \\
\text { SCMD2 } \\
\text { SCMD3 } \\
\text { SCMD4 }\end{array}$ & $\begin{array}{l}0.894 \\
0.885 \\
0.923 \\
0.887\end{array}$ & 0.943 & 0.806 \\
\hline $\begin{array}{l}\text { Big data based supply chain } \\
\text { technology management knowledge } \\
\text { (SCTM) }\end{array}$ & $\begin{array}{l}\text { SCTM1 } \\
\text { SCTM2 } \\
\text { SCTM3 } \\
\text { SCTM4 }\end{array}$ & $\begin{array}{l}0.882 \\
0.915 \\
0.906 \\
0.884\end{array}$ & 0.945 & 0.804 \\
\hline $\begin{array}{l}\text { Big data-based supply chain } \\
\text { technical knowledge } \\
\text { (SCTK) }\end{array}$ & $\begin{array}{l}\text { SCTK1 } \\
\text { SCTK2 } \\
\text { SCTK3 } \\
\text { SCTK4 }\end{array}$ & $\begin{array}{l}0.877 \\
0.908 \\
0.906 \\
0.898\end{array}$ & 0.943 & 0.805 \\
\hline $\begin{array}{l}\text { Big data-based supply chain } \\
\text { business knowledge } \\
\text { (SCBK) }\end{array}$ & $\begin{array}{l}\text { SCBK1 } \\
\text { SCBK2 } \\
\text { SCBK3 } \\
\text { SCBK4 }\end{array}$ & $\begin{array}{l}0.886 \\
0.918 \\
0.923 \\
0.905\end{array}$ & 0.949 & 0.824 \\
\hline $\begin{array}{l}\text { Big data-based supply chain } \\
\text { relational knowledge } \\
\text { (SCRK) }\end{array}$ & $\begin{array}{l}\text { SCRK1 } \\
\text { SCRK2 } \\
\text { SCRK3 } \\
\text { SCRK4 }\end{array}$ & $\begin{array}{l}0.893 \\
0.924 \\
0.895 \\
0.905\end{array}$ & 0.947 & 0.817 \\
\hline $\begin{array}{l}\text { Big data-driven supply chain agility } \\
\text { (SCAG) }\end{array}$ & $\begin{array}{l}\text { SCAG1 } \\
\text { SCAG2 } \\
\text { SCAG3 } \\
\text { SCAG4 } \\
\text { SCAG5 }\end{array}$ & $\begin{array}{l}0.879 \\
0.890 \\
0.858 \\
0.873 \\
0.905\end{array}$ & 0.945 & 0.776 \\
\hline $\begin{array}{l}\text { Firm performance } \\
\text { (FPER) }\end{array}$ & $\begin{array}{l}\text { FPER1 } \\
\text { FPER2 } \\
\text { FPER3 } \\
\text { FPER4 }\end{array}$ & $\begin{array}{l}0.903 \\
0.915 \\
0.902 \\
0.919\end{array}$ & 0.950 & 0.828 \\
\hline Formative construct & Items & Weights & t-value & VIF \\
\hline $\begin{array}{l}\text { Situational and demographic control } \\
\text { variables } \\
\text { (COVA) }\end{array}$ & $\begin{array}{l}\text { Experience } \\
\text { Industry } \\
\text { Firm’s size } \\
\text { Age } \\
\text { Gender } \\
\text { Education }\end{array}$ & $\begin{array}{l}-0.351 \\
0.363 \\
0.012 \\
0.879 \\
0.188 \\
-0.145\end{array}$ & $\begin{array}{l}1.611 \\
2.163 \\
0.064 \\
5.883 \\
0.925 \\
0.791\end{array}$ & $\begin{array}{l}1.2771 \\
1.0974 \\
1.1108 \\
1.2069 \\
1.0454 \\
1.0208\end{array}$ \\
\hline
\end{tabular}


Table 3: Correlations of LVs, AVEs and Descriptive Statistics*

\begin{tabular}{|c|c|c|c|c|c|c|c|c|c|c|c|c|c|c|c|c|}
\hline Construct & Mean & $S D$ & $S C P L$ & SCID & SCCO & SCCT & SCCN & SCCM & SCMD & SCTM & SCTK & $S C B K$ & SCRK & $S C A G$ & FPER & COVA \\
\hline $\begin{array}{l}\text { Supply chain planning } \\
\text { (SCPL) }\end{array}$ & 5.645 & 1.305 & 0.919* & & & & & & & & & & & & & \\
\hline $\begin{array}{l}\text { Supply chain investment } \\
\text { decision (SCID) }\end{array}$ & 5.675 & 1.247 & 0.535 & $0.903 *$ & & & & & & & & & & & & \\
\hline $\begin{array}{l}\text { Supply chain coordination } \\
\text { (SCCO) }\end{array}$ & 5.582 & 1.327 & 0.532 & 0.535 & 0.897* & & & & & & & & & & & \\
\hline $\begin{array}{l}\text { Supply chain control } \\
\text { (SCCT) }\end{array}$ & 5.677 & 1.312 & 0.506 & 0.552 & 0.608 & $0.911^{*}$ & & & & & & & & & & \\
\hline $\begin{array}{l}\text { Supply chain connectivity } \\
\text { (SCCN) }\end{array}$ & 5.522 & 1.370 & 0.497 & 0.547 & 0.586 & 0.586 & 0.893* & & & & & & & & & \\
\hline $\begin{array}{l}\text { Supply chain } \\
\text { compatibility (SCCM) }\end{array}$ & 5.572 & 1.296 & 0.462 & 0.506 & 0.562 & 0.568 & 0.552 & $0.909 *$ & & & & & & & & \\
\hline $\begin{array}{l}\text { Supply chain modularity } \\
\text { (SCMD) }\end{array}$ & 5.575 & 1.330 & 0.437 & 0.467 & 0.562 & 0.555 & 0.582 & 0.597 & 0.897* & & & & & & & \\
\hline $\begin{array}{l}\text { Supply chain technology } \\
\text { management knowledge } \\
\text { (SCTM) }\end{array}$ & 5.697 & 1.265 & 0.458 & 0.481 & 0.512 & 0.540 & 0.539 & 0.531 & 0.550 & $0.896^{*}$ & & & & & & \\
\hline $\begin{array}{l}\text { Supply chain technical } \\
\text { knowledge (SCTK) }\end{array}$ & 5.667 & 1.272 & 0.471 & 0.540 & 0.537 & 0.590 & 0.555 & 0.586 & 0.580 & 0.587 & $0.897 *$ & & & & & \\
\hline $\begin{array}{l}\text { Supply chain business } \\
\text { knowledge } \\
\text { (SCBK) }\end{array}$ & 5.750 & 1.195 & 0.491 & 0.457 & 0.490 & 0.511 & 0.513 & 0.505 & 0.532 & 0.604 & 0.569 & $0.907^{*}$ & & & & \\
\hline $\begin{array}{l}\text { Supply chain relational } \\
\text { knowledge (SCRK) }\end{array}$ & 5.767 & 1.222 & 0.471 & 0.511 & 0.537 & 0.590 & 0.555 & 0.586 & 0.581 & 0.573 & 0.540 & 0.589 & 0.904* & & & \\
\hline $\begin{array}{l}\text { Supply chain agility } \\
\text { (SCAG) }\end{array}$ & 5.714 & 1.205 & 0.463 & 0.449 & 0.452 & 0.486 & 0.491 & 0.476 & 0.481 & 0.534 & 0.505 & 0.547 & 0.550 & $0.880^{*}$ & & \\
\hline $\begin{array}{l}\text { Performance of the firm } \\
\text { (FPER) }\end{array}$ & 5.752 & 1.175 & 0.409 & 0.395 & 0.430 & 0.449 & 0.456 & 0.444 & 0.477 & 0.519 & 0.507 & 0.546 & 0.520 & 0.554 & $0.909 *$ & \\
\hline $\begin{array}{l}\text { Control Variables } \\
\text { (COVA) }\end{array}$ & n.a. & n.a. & -0.282 & -0.301 & -0.343 & -0.343 & -0.313 & -.400 & -0.391 & -0.340 & -0.393 & -0.330 & -0.296 & -0.306 & -0.312 & n.a. \\
\hline
\end{tabular}

*square root of AVE on the diagonal 


\section{Higher-Order Measurement Model}

Due to the hierarchical nature of the research model, we calculated the measurement properties of the second-order management, technology and talent constructs and third-order supply chain analytics (SCAC) construct. The highest-order SCAC construct represents forty-four indicators. The formative nature of the highest-order SCAC construct indicates that its relationship with second-order constructs is significant $(\mathrm{p}<0.05)$. For example, management capability explains $36 \%$ of variance, technology capability explains $28 \%$ of the variance and talent capability explains 39\% of variance in SCAC. Table 4 shows that management capability was reflected by planning (92\%), investment decision-making (94\%), coordination (95\%) and control (95\%). Similarly, technology capability was explained by connectivity (95\%), compatibility (96\%), and compatibility (96\%). Finally, technology capability was explained by business knowledge (96\%), technology management knowledge (96\%), technical knowledge (94\%) and relationship knowledge (94\%), which are significant at $\mathrm{p}<0.01$ through the path coefficients between second-order and third-order constructs.

Table 4: Assessment of the Higher-order, Reflective Model

\begin{tabular}{|c|c|c|c|c|c|c|c|}
\hline Models & Latent constructs & AVE & CR & Dimensions & \multicolumn{2}{|c|}{$\beta$} & t-statistic \\
\hline $\begin{array}{l}\text { Third- } \\
\text { order }\end{array}$ & $\begin{array}{l}\text { Supply Chain Analytics } \\
\text { Capability (SCAC) }\end{array}$ & 0689 & 0.989 & $\begin{array}{l}\text { SCMAC } \\
\text { SCTEC } \\
\text { SCTLC }\end{array}$ & \multicolumn{2}{|c|}{$\begin{array}{l}0.362 \\
0.281 \\
0.391\end{array}$} & $\begin{array}{l}53.726 \\
57.220 \\
50.091\end{array}$ \\
\hline Models & Latent constructs & AVE & CR & Dimensions & $\beta$ & R square & $t$-statistic \\
\hline \multirow[t]{3}{*}{$\begin{array}{l}\text { Second- } \\
\text { order }\end{array}$} & $\begin{array}{l}\text { Supply Chain } \\
\text { Management Capability } \\
\text { (SCMAC) }\end{array}$ & 0.728 & 0.977 & $\begin{array}{l}\text { SCPL } \\
\text { SCID } \\
\text { SCCO } \\
\text { SCCT }\end{array}$ & $\begin{array}{l}0.924 \\
0.937 \\
0.951 \\
0.949\end{array}$ & $\begin{array}{l}0.853 \\
0.878 \\
0.905 \\
0.901\end{array}$ & $\begin{array}{l}53.423 \\
56.037 \\
111.429 \\
104.409\end{array}$ \\
\hline & $\begin{array}{l}\text { Supply Chain } \\
\text { Technology Capability } \\
\text { (SCTEC) }\end{array}$ & 0.745 & 0.972 & $\begin{array}{l}\text { SCCN } \\
\text { SCCM } \\
\text { SCMD }\end{array}$ & $\begin{array}{l}0.950 \\
0.958 \\
0.967\end{array}$ & $\begin{array}{l}0.903 \\
0.917 \\
0.935\end{array}$ & $\begin{array}{l}66.741 \\
134.474 \\
136.737\end{array}$ \\
\hline & $\begin{array}{l}\text { Supply Chain Talent } \\
\text { Capability (SCTLC) }\end{array}$ & 0.737 & 0.978 & $\begin{array}{l}\text { SCTM } \\
\text { SCTK } \\
\text { SCBK } \\
\text { SCRK }\end{array}$ & $\begin{array}{l}0.961 \\
0.943 \\
0.962 \\
0.945\end{array}$ & $\begin{array}{l}0.924 \\
0.891 \\
0.925 \\
0.893\end{array}$ & $\begin{array}{l}132.782 \\
65.388 \\
125.407 \\
86.523\end{array}$ \\
\hline
\end{tabular}




\section{Structural Model}

Table 5 shows the validity of the structural model by estimating the path coefficients, $t-$ statistics and the R square (Falk and Miller 1992) (Stone 1974, Geisser 1975). The findings provided a standardized path coefficient of 0.386 from SCAC to FPER (H1), 0.865 from SCAC to SCAG (H2) and 0.515 from SCAG to FPER (H3). The findings of the study confirm the significance of these path coefficients, thus supporting H1-H3.

Table 5: Results of the Structural Model

\begin{tabular}{|c|c|c|c|c|c|c|}
\hline Hypotheses & \multicolumn{3}{|c|}{ Main Model } & Path & Standard & $t$-statistic \\
\hline $\mathrm{H} 1$ & SCAC & $\longrightarrow$ & FPER & 0.386 & 0.0977 & 3.9581 \\
\hline H2 & SCAC & 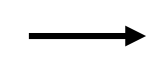 & SCAG & 0.865 & 0.0320 & 27.086 \\
\hline H3 & SCAG & 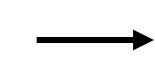 & FPER & 0.515 & 0.0999 & 5.1580 \\
\hline
\end{tabular}

The study followed the guidelines proposed by Preacher and Hayes (2008) to estimate the indirect (or, mediating) effect of SCAG between SCAC-SCAG-FPER link using bootstrapping on a 95\% of confidence interval. The findings show that the size of the mediating effect is 0.445 , which is the product of the path coefficients from SCAC to SCAG and from SCAG to FPER significant at $\mathrm{p}<0.01$. Overall, the study proved that SCAG is a significant partial mediator between SCAC and FPER, thus supporting H4 (Hair Jr, Hult et al. 2017).

\section{Additional Analyses}

Following Armstrong \& Overton’s (1977) guidelines, this study conducted a non-response bias analysis. First of all, the first and the last quarter of the pilot data $(n=71)$ were compared for each first-order SCAC response. The findings did not show any significant variation 
across the constructs, and no non-response bias was found in the pilot study. Then, the main study ( $\mathrm{n}=281$ ) followed the same procedure by using the first and last $10 \%$ of respondents across the first-order SCAC constructs. The findings were consistent with the first-round, and no concern of non-response bias was noticed. Finally, a comparison test was made with the data from Study 2 (i.e., main study) and Study 1 (i.e., pilot study), and the chi-squared tests did not present any significant difference ( $p>0.05$, that is, Study1= Study 2 ) in terms of demographic characteristics (e.g., gender, age, education, experience) (Stanko, Molina -

Castillo et al. 2012; Akter, Fosso Wamba et al. 2016). In addition, the potential risk of CMV from a single-respondent survey design was addressed using research design and statistical techniques. This implies that (i) the study established a psychological separation between antecedents and outcome variables to ensure adequate causality in the relationship; and (ii) the Herman's single-factor test was conducted, and no construct was found to be contributing for more than $30 \%$ to the variance (Podsakoff and Organ 1986). To address the limitation of this test, we also applied the marker variable technique (Lindell and Whitney 2001) by including a weakly related item as a marker variable in the SEM model. Overall, we did not find any significant relationship between the marker variable and any construct, which means that no CMV was found in the study.

\section{DISCUSSION}

The study addressed three research questions as follows: (i) what are the dimensions of supply chain analytics capabilities (SCACs) (ii) is there any impact on SCACs on firm performance? and (iii) Is there any mediating effect of supply chain agility between SCAC and performance? We answered these questions by conceptualizing hierarchical SCACs as dynamic capabilities, which are able to sense, seize and reconfigure operations by rendering them more agile. Upon the development and validation of SCACs as dynamic capabilities, we were in a position to 
model their overall effects on outcome construct and to assess the mediating effects of supply chain agility.

The findings show that supply chain talent capability (SCTLC) emerged as the strongest second-order construct ( $\beta=0.391)$ to form dynamic SCAC. Ransbotham, Kiron et al. (2015) highlight the role of talent capability in gaining a competitive advantage with big data analytics. In addition, the role of supply chain management capability (SCMAC) was selected as a critical construct $(\beta=0.362)$ implying that accelerating firm performance with SCACs relies heavily on decision-makers. Finally, supply chain technology capability (SCTEC) was found as a significant dimension $(\beta=0.281)$, emphasizing the need for establishing a robust technology platform using big data, AI and machine learning. For example, Davenport (2013, p.67) highlights that "innovative technologies of many kinds had to be created, acquired, and mastered... To complement them, new "agile” analytical methods and machine-learning techniques are being used to produce insights at a much faster rate”. Although the findings showed the rank order importance of three SCAC dimensions, all the dimensions are equally important as the magnitude of difference among them are minimal.

The findings show that the importance of overall SCAC is associated with construct and sub construct levels. For example, the role of supply chain management capability (SCMAC) is determined by the level of planning, investment, coordination, and control. Similarly, technology and talent capability could be improved by enhancing their sub-dimensions respectively. These findings have a direct impact on industries such as, retail, manufacturing, healthcare, which constantly struggle to develop analytics capabilities. For example, by developing SCAC and agility, supply chain managers could enhance firm performance and thus create new products and services (70\%), increase sales and revenue (76\%) and expand into new markets (72\%) (Columbus 2014). Overall, the findings of the study propose SCAC as a driver of accelerating FPER (explaining $77 \%$ of the variance) by establishing robust 
agility in operations ( $44 \%$ of the variance). Overall, the empirical findings of our study answer our research, and provide adequate evidence for the conceptual foundation of Kiron, Prentice et al. (2014, p.10) , "an analytics culture is built on the backs of more advanced data management processes, technologies and talent”.

Before discussing the implications of our study, it is important to highlight some of the limitations related to this study. First, the study uses a cross-sectional study as a quick, easy and cost-effective way to collect data among supply chain professionals, managers and midlevel managers in the USA (Sedgwick 2014), thus using only one data collection point. Future studies should consider using a mixed-methods research approach that combines the strengths of qualitative and quantitative approaches to study the adoption, use and impact of BDA in the supply chain (Venkatesh, Brown et al. 2016). Another research avenue is the use of a longitudinal case study to validate our current research findings. Second, the data collection was done only in the USA, future studies should consider collecting data in various countries with different cultural and economic characteristics (e.g., developing and developed countries).

\section{IMPLICATIONS FOR RESEARCH}

This study has several theoretical implications for key issues such as data-driven supply chain analytics capability, supply chain agility and firm performance. Although the findings of our study are aligned with the results of a number of operations and supply chain management studies (see, Kristal et al. 2010; Blome et al. 2013; Aslam et al. 2018), supply chain agility driven by big data-driven analytics capability has become an important challenge in operations discourse and no consensus has been reached on how to resolve this dilemma. In their recent attempts to bridge the gap, Dubey et al. (2018, 2019) Srinivasan and Swink (2018) and Chen et al. (2015) failed to articulate the SCAC dimensions and their effects on SCAG 
and FPER. By integrating findings from RBV, DC and emerging big data theories, we have achieved some success, which has specific theoretical implications. The first of them is that this study has pioneered the conceptualization of supply chain analytics capability, the modeling of its impact on firm performance and the evaluation of the mediating effect of supply chain agility on the relationship between SCAC and firm performance. Hence, the study extends the research stream big data analytics capability (Akter, Fosso Wamba et al. 2016, Fosso Wamba, Gunasekaran et al. 2017) using the dynamic capability theory in the supply chain context. The second implication is that this study tested and confirmed the mediating effect of supply chain agility on the relationship between supply chain analytics capability and firm performance, and thus confirmed the importance of investing in complementary assets (e.g., supply chain agility) to leverage a firm analytics platform (Kohli and Grover 2008, Anand, Fosso Wamba et al. 2013). By doing so, the study proposes an integrated model that links supply chain analytics capability, supply chain agility and firm

performance. While this study extends directly the modeling of supply chain analytics capability, our findings that supply chain agility plays an instrumental role between analytics capability and firm performance (Srinivasan and Swink, 2018, Gunasekaran et al. 2017) challenges the existing assumption that big data analytics capability is the only solution for superior supply chain performance (see, Akter et al. 2016, Wamba et al. 2017).

\section{IMPLICATIONS FOR PRACTICE}

Our findings identified a significant positive relationship between SCAC and firm performance as well as a mediating effect of supply chain agility on this relationship. These findings could guide managers' decisions to invest in SCAC.They should also consider investing in complementary assets such as supply chain agility in order to achieve a high-level suistained competitive advantage. Furthermore, firms should invest in an appropriate business 
model enabled by SCAC (Hartmann, Zaki et al. 2016). it should be noted that this study identified the three main subconstructs of analytics capability in the supply chain context on which managers should focus when exploring the adoption and use of big data. The findings of the study can be used as a diagnostic tool to identify gaps in big data analytics capability. For example, the model obtained can help managers to identify any analytics sub-dimension that is lowly performant and poorly contributes to a particular dimension (i.e., talent, technology or, management). The measurement of the relative contribution of any particular dimension to agility and performance can also rely on the findings of this study.

\section{CONCLUSION, LIMITATIONS AND THE WAY FORWARD}

In terms of contributions, this study has succeeded in identifying the key constructs and subconstructs that are required by SCAC for improved firm performance, and, thus, help in a better understanding of the SCAC construct within the emerging big data literature. The second contribution resides in that this study tested the direct impact of SCAC on FPER as well as the mediating effect of SCAG on this relationship. Drawing on the emerging literature on big data, RBV and the DCT, and based on data collected from 281 supply chain managers in the USA, this study found a positive significant impact of SCAC on FPER and the mediating effects of SCAG on this relationship. This study contributes to the understanding of big data adoption, use and impact at the firm and the supply chain levels. Our proposed research model can be used as a baseline model for future studies on BDA-enabled supply chain optimization.

This study is bounded in many ways. First, we only consider SCAG as the single mediator of the relation between SCAC and FPER. However, just aligning the SCAC and FPER is not enough. Future studies should consider integrating more capabilities such as supply chain adaptability, and other alignments that could mediate the relation between SCAC and FPER (Rameshwar, Nezih et al. 2018). Second, while this study provides some important 
dimensions of SCAC needed to foster firm performance, more investigations are welcome for the holistic IT infrastructure that is needed to capture and share real-time information across the supply chain, and thus support big data, emerging processes and people's activities (Kache and Seuring 2017); and the ultimate gold remains an improved decision-making process and a suistained competitive advantage (Brinch 2018). Another future research avenue should consist in exploring the impact of investing in big data in order to create a higher-order capabilities or dynamic capabilities that will be used to sense customers needs and market opportunities, mobilize the required resources to seize opportunities (or the seizing capability) and readjust them to face the identified customers' needs and market opportunities (or the reconfiguring capability) (Teece 2014). Third, this study uses a survey-based questionnaire to collect data, which holds the risk of self-report bias (Fosso Wamba, Bhattacharya et al. 2017). Therefore, future studies should consider using case studies or longitudinal studies to validate our current findings and uncover the impact of the lag effect of big data investments (Kohli and Grover 2008). 


\section{REFERENCES}

Akter, S., S. Fosso Wamba, A. Gunasekaran, R. Dubey and S. J. Childe (2016). "How to improve firm performance using big data analytics capability and business strategy alignment?" International Journal of Production Economics 182: 113-131.

Akter, S., S. F. Wamba, A. Gunasekaran, R. Dubey and S. J. Childe (2016). "How to improve firm performance using big data analytics capability and business strategy alignment?" International Journal of Production Economics 182: 113-131.

Anand, A., S. Fosso Wamba and R. Sharma (2013). The effects of firm IT capabilities on firm performance: the mediating effects of process improvement. 24th Australasian Conference on Information Systems Melbourne, Australia: 1-10.

Augier, M. and D. J. Teece (2009). "Dynamic Capabilities and the Role of Managers in Business Strategy and Economic Performance." Organization Science 20(2): 410-421.

Barney, J. (1991). "Firm resources and sustained competitive advantage." Journal of management 17(1): 99-120.

Barney, J. B. (1991). "Firm resources and sustained competitive advantage." Journal of Management 17: 99-120.

Barney, J. B. (2001). "Resource-based theories of competitive advantage: A ten-year retrospective on the resource-based view." Journal of Management 27(6): 643-650.

Barton, D. and D. Court (2012). "Making advanced analytics work for you." Harvard business review 90(10): 78.

Becker, J., D. F. Beverungen and R. Knackstedt (2010). "The challenge of conceptual modeling for product-service systems: status-quo and perspectives for reference models and modeling languages." Information Systems and E-Business Management 8(1): 33-66.

Blome, C., T. Schoenherr and D. Rexhausen (2013). "Antecedents and enablers of supply chain agility and its effect on performance: a dynamic capabilities perspective." International Journal of Production Research 51(4): 1295-1318.

Boar, B. H. (1995). Cost-effective strategies for client/server systems, John Wiley \& Sons, Inc.

Bowers, M. R., A. G. Petrie and M. C. Holcomb (2017). "Unleashing the Potential of Supply Chain Analytics." MIT Sloan Management Review 59(1): 14-16.

Boynton, A. C., R. W. Zmud and G. C. Jacobs (1994). "The influence of IT management practice on IT use in large organizations." Mis Quarterly: 299-318.

Brinch, M. (2018). "Understanding the value of big data in supply chain management and its business processes: Towards a conceptual framework." International Journal of Operations \& Production Management 38(7): 1589-1614.

Broadbent, M., P. Weill and D. St. Clair (1999). "The implications of information technology infrastructure for business process redesign." MIS quarterly: 159-182.

Cavusgil, E., S. H. Seggie and M. B. Talay (2007). "Dynamic Capabilities View: Foundations and Research Agenda." Journal of Marketing Theory and Practice 15(2): 159-166.

Cerruti, C., C. Mena, H. Skipworth and E. Tavoletti (2016). "Characterizing agile supply partnerships in the fashion industry." International Journal of Operations \& Production Management 36(8): 923-947.

Chae, B., D. Olson and C. Sheu (2014). "The impact of supply chain analytics on operational performance: a resource-based view." International Journal of Production Research 52(16): 4695-4710.

Chan, A. T. L., E. W. T. Ngai and K. K. L. Moon (2017). "The effects of strategic and manufacturing flexibilities and supply chain agility on firm performance in the fashion industry." European Journal of Operational Research 259(2): 486-499. 
Chen, Y., Y. Wang, S. Nevo, J. Jin, L. Wang and W. S. Chow (2014). "IT capability and organizational performance: the roles of business process agility and environmental factors." European Journal of Information Systems 23(3): 326-342.

Chiang, C. Y., C. Kocabasoglu-Hillmer and N. Suresh (2012). "An empirical investigation of the impact of strategic sourcing and flexibility on firm's supply chain agility." International Journal of Operations \& Production Management 32(1): 49-78.

Chin, W. W. (1998). "Commentary: Issues and opinion on structural equation modeling." MIS Quarterly.

Chin, W. W. (1998). "The partial least squares approach for structural equation modeling."

Chin, W. W. (2010). "How to write up and report PLS analyses." Handbook of partial least squares: 655-690.

Columbus, L. (2014, 12/10/2014). "Making Analytics Accountable: 56\% Of Executives Expect Analytics to Contribute To 10\% Or More Growth in 2014." Forbes Retrieved 11/12/2014, 2014, from http://www.forbes.com/sites/louiscolumbus/2014/12/10/makinganalytics-accountable-56-of-executives-expect-analytics-to-contribute-to-10-or-more-growthin-2014/.

Davenport, T. H. (2013). "Analytics 3.0." Harvard Business Review 91(12): 64-72.

DeGroote, S. E. and T. G. Marx (2013). "The impact of IT on supply chain agility and firm performance: An empirical investigation." International Journal of Information Management 33(6): 909-916.

DeSanctis, G. and B. M. Jackson (1994). "Coordination of information technology management: Team-based structures and computer-based communication systems." Journal of Management Information Systems: 85-110.

Dubey, R., N. Altay, A. Gunasekaran, C. Blome, T. Papadopoulos and S. J. Childe (2018). "Supply chain agility, adaptability and alignment: Empirical evidence from the Indian auto components industry." International Journal of Operations \& Production Management 38(1): 129-148.

Dubey, R., A. Gunasekaran, S. J. Childe, C. Blome and T. Papadopoulos (2019). "Big Data and Predictive Analytics and Manufacturing Performance: Integrating Institutional Theory, Resource-Based View and Big Data Culture." British Journal of Management 30(2): 341-361. Dubey, R., A. Gunasekaran, S. J. Childe, S. Fosso Wamba, D. Roubaud and C. Foropon (2019). "Empirical investigation of data analytics capability and organizational flexibility as complements to supply chain resilience." International Journal of Production Research: 1-19.

Dubey, R., T. Singh and O. K. Gupta (2015). "Impact of Agility, Adaptability and Alignment on Humanitarian Logistics Performance: Mediating Effect of Leadership." Global Business Review 16(5): 812-831.

Duncan, N. B. (1995). "Capturing flexibility of information technology infrastructure: A study of resource characteristics and their measure." Journal of Management Information Systems: 37-57.

Dwayne Whitten, G., K. W. Green and P. J. Zelbst (2012). "Triple-A supply chain performance." International Journal of Operations \& Production Management 32(1): 28-48.

Eckstein, D., M. Goellner, C. Blome and M. Henke (2015). "The performance impact of supply chain agility and supply chain adaptability: the moderating effect of product complexity." International Journal of Production Research 53(10): 3028-3046.

Efron, B. and R. Tibshirani (1993). An introduction to the bootstrap, Chapman \& Hall/CRC. Ellinger, A. E., M. Natarajarathinam, F. G. Adams, J. B. Gray, D. Hofman and K. O'Marah (2011). "Supply Chain Management Competency and Firm Financial Success." Journal of Business Logistics 32(3): 214-226.

Falk, R. F. and N. B. Miller (1992). A primer for soft modeling, University of Akron Press. Fornell, C. and F. L. Bookstein (1982). "Two structural equation models: LISREL and PLS applied to consumer exit-voice theory." Journal of Marketing Research: 440-452. 
Fornell, C. and D. F. Larcker (1981). "Evaluating structural equation models with unobservable variables and measurement error." Journal of Marketing Research: 39-50.

Fosso Wamba, S., S. Akter, A. Edwards, G. Chopin and D. Gnanzou (2015). "How 'big data' can make big impact: Findings from a systematic review and a longitudinal case study." International Journal of Production Economics 165: 234-246.

Fosso Wamba, S., M. Bhattacharya, L. Trinchera and E. W. T. Ngai (2017). "Role of intrinsic and extrinsic factors in user social media acceptance within workspace: Assessing unobserved heterogeneity." International Journal of Information Management 37(2): 1-13.

Fosso Wamba, S., A. Gunasekaran, S. Akter, S. J.-f. Ren, R. Dubey and S. J. Childe (2017). "Big data analytics and firm performance: Effects of dynamic capabilities." Journal of Business Research 70: 356-365.

Geisser, S. (1975). "The predictive sample reuse method with applications." Journal of the American Statistical Association 70(350): 320-328.

Gheorghe, M., P. Massimo and I. Alexandra (2015). "BIG DATA IN SUPPLY CHAIN MANAGEMENT: AN EXPLORATORY STUDY." Network Intelligence Studies, Vol III, Iss 6 (2/2015), Pp 103-108 (2015)(6 (2/2015)): 103.

Giannakis, M. and M. Louis (2016). "A multi-agent based system with big data processing for enhanced supply chain agility." Journal of Enterprise Information Management 29(5): 706727.

Gligor, D. M. (2014). "A Cross-Disciplinary Examination of Firm Orientations' Performance Outcomes: The Role of Supply Chain Flexibility." Journal of Business Logistics 35(4): 281298.

Gligor, D. M., C. L. Esmark and M. C. Holcomb (2015). "Performance outcomes of supply chain agility: When should you be agile?" Journal of Operations Management 33-34: 71-82.

Gligor, D. M. and M. C. Holcomb (2012). "Antecedents and Consequences of Supply Chain Agility: Establishing the Link to Firm Performance." Journal of Business Logistics 33(4): 295-308.

Gunasekaran, A., T. Papadopoulos, R. Dubey, S. F. Wamba, S. J. Childe, B. Hazen and S. Akter (2017). "Big data and predictive analytics for supply chain and organizational performance." Journal of Business Research 70: 308-317.

Hair, J. F., G. T. M. Hult, C. Ringle and M. Sarstedt (2013). A primer on partial least squares structural equation modeling (PLS-SEM), SAGE Publications, Incorporated.

Hair, J. F., C. M. Ringle and M. Sarstedt (2011). "PLS-SEM: Indeed a silver bullet." The Journal of Marketing Theory and Practice 19(2): 139-152.

Hair Jr, J. F., G. T. M. Hult, C. Ringle and M. Sarstedt (2013). A primer on partial least squares structural equation modeling (PLS-SEM), Sage Publications.

Hair Jr, J. F., G. T. M. Hult, C. M. Ringle and M. S. Sarstedt (2017). A primer on partial least squares structural equation modeling (PLS-SEM), Sage Publications.

Han, J. H., Y. Wang and M. Naim (2017). "Reconceptualization of information technology flexibility for supply chain management: An empirical study." International Journal of Production Economics 187: 196-215.

Hartmann, P. M., M. Zaki, N. Feldmann and A. Neely (2016). "Capturing value from big data - a taxonomy of data-driven business models used by start-up firms." International Journal of Operations \& Production Management 36(10): 1382-1406.

Hitt, M. A., K. Xu and C. M. Carnes (2016). "Resource based theory in operations management research." Journal of Operations Management 41: 77-94.

Hoopes, D. G., T. L. Madsen and G. Walker (2003). "Guest editors' introduction to the special issue: why is there a resource-based view? Toward a theory of competitive heterogeneity." Strategic Management Journal 24(10): 889-902. 
I. van Hoek, R., A. Harrison and M. Christopher (2001). "Measuring agile capabilities in the supply chain." International Journal of Operations \& Production Management 21(1/2): 126148.

Jiang, J. J., G. Klein, C. V. Slyke and P. Cheney (2003). "A note on interpersonal and communication skills for IS professionals: Evidence of positive influence." Decision Sciences 34(4): 799-812.

Kache, F. and S. Seuring (2017). "Challenges and opportunities of digital information at the intersection of Big Data Analytics and supply chain management." International Journal of Operations \& Production Management 37(1): 10-36.

Karimi, J., T. M. Somers and Y. P. Gupta (2001). "Impact of information technology management practices on customer service." Journal of Management Information Systems 17(4): 125-158.

Khanchanapong, T., D. Prajogo, A. S. Sohal, B. K. Cooper, A. C. L. Yeung and T. C. E. Cheng (2014). "The unique and complementary effects of manufacturing technologies and lean practices on manufacturing operational performance." International Journal of Production Economics 153: 191-203.

Kim, G., B. Shin, K. K. Kim and H. G. Lee (2011). "IT capabilities, process-oriented dynamic capabilities, and firm financial performance." Journal of the Association for Information Systems 12: 487-517.

Kim, G., B. Shin and O. Kwon (2012). "Investigating the Value of Sociomaterialism in Conceptualizing IT Capability of a Firm." Journal of Management Information Systems 29(3): 327-362.

Kiron, D., P. K. Prentice and R. B. Ferguson (2014). "The Analytics Mandate." MIT Sloan Management Review 55(4): 1-25.

Kohli, R. and V. Grover (2008). "Business Value of IT: An Essay on Expanding Research Directions to Keep up with the Times *." Journal of the Association for Information Systems 9(1): 23-28,30-34,36-39.

Kude, T., H. Hoehle and T. A. Sykes (2017). "Big data breaches and customer compensation strategies: Personality traits and social influence as antecedents of perceived compensation." International Journal of Operations \& Production Management 37(1): 56-74.

Lail, E. and J. Richardson (2015). "The Marriage of Lean and Supply Chain Analytics." Material Handling \& Logistics 70(3): 29-31.

Lee, D. M., E. M. Trauth and D. Farwell (1995). "Critical skills and knowledge requirements of IS professionals: a joint academic/industry investigation." MIS quarterly: 313-340.

Li, E. Y., J. J. Jiang and G. Klein (2003). "The impact of organizational coordination and climate on marketing executives' satisfaction with information systems services." Journal of the Association for Information Systems 4(1): 4.

Lin, B.-W. (2007). "Information technology capability and value creation: Evidence from the US banking industry." Technology in Society 29(1): 93-106.

Lindell, M. K. and D. J. Whitney (2001). "Accounting for common method variance in crosssectional research designs." Journal of applied psychology 86(1): 114.

Liu, H., W. Ke, K. K. Wei and Z. Hua (2013). "The impact of IT capabilities on firm performance: The mediating roles of absorptive capacity and supply chain agility." Decision Support Systems 54(3): 1452-1462.

Lopez, E. (2017). "What is Big Data, and why does it matter to supply chain?" Retrieved February 19, 2018, from https://www.supplychaindive.com/news/what-Big-Data-supplychain-application-primer/435865/.

Manyika, J., M. Chui, B. Brown, J. Bughin, R. Dobbs, C. Roxburgh and A. H. Byers (2011). Big data: the next frontier for innovation, competition and productivity, McKinsey Global Institute. 
McAfee, A. and E. Brynjolfsson (2012). "Big data: the management revolution." Harvard business review(90): 60-66, 68, 128.

McCrea, B. (2017). "6 ways BIG DATA is enhancing the global supply chain." Logistics Management 56(9): 64S.

Mikalef, P., M. Boura, G. Lekakos and J. Krogstie (2019). "Big data analytics capabilities and innovation: the mediating role of dynamic capabilities and moderating effect of the environment." British Journal of Management 30(2): 272-298.

Najafi Tavani, S., H. Sharifi and H. S. Ismail (2013). "A study of contingency relationships between supplier involvement, absorptive capacity and agile product innovation." International Journal of Operations \& Production Management 34(1): 65-92.

Newswire (2015). Supply Chain Analytics Market Worth \$4.8 Billion by 2019. bcMarketsandMarkets, Y.

Newswire (2017). Global Supply Chain Analytics Market 2017-2021. NY-Reportlinker, Y.

Newswire (2017). Supply Chain Analytics Market Expected to Reach Almost 10 Billion Dollars by 2025, M2PressWIRE.

Ngai, E. W. T., D. C. K. Chau and T. L. A. Chan (2011). "Information technology, operational, and management competencies for supply chain agility: Findings from case studies." The Journal of Strategic Information Systems 20(3): 232-249.

Orenstein, P., D. Ladik and S. Rainford (2016). "What are the Key Drivers of Future Supply Chains?" Journal of Accounting, Business \& Management 23(1): 31-40.

Peteraf, M. A. and J. B. Barney (2003). "Unraveling the resource-based tangle." Managerial and decision economics 24(4): 309-323.

Podsakoff, P. M. and D. W. Organ (1986). "Self-reports in organizational research: Problems and prospects." Journal of management 12(4): 531-544.

Preacher, K. J. and A. F. Hayes (2008). "Asymptotic and resampling strategies for assessing and comparing indirect effects in multiple mediator models." Behavior research methods 40(3): 879-891.

Priem, R. L. and J. E. Butler (2001). "Is the Resource-Based "View" a Useful Perspective for Strategic Management Research?" The Academy of Management Review 26(1): 22-40.

Priem, R. L. and J. E. Butler (2001). "Tautology in the Resource-Based View and the Implications of Externally Determined Resource Value: Further Comments." The Academy of Management Review 26(1): 57-66.

Rameshwar, D., A. Nezih, G. Angappa, B. Constantin, P. Thanos and C. S. J. (2018). "Supply chain agility, adaptability and alignment: Empirical evidence from the Indian auto components industry." International Journal of Operations \& Production Management 38(1): 129-148.

Ransbotham, S., D. Kiron and P. K. Prentice (2015). "Minding the Analytics Gap." MIT Sloan Management Review 56(3): 63-68.

Ransbotham, S., D. Kiron and P. K. Prentice (2015). "The Talent Dividend." MIT Sloan Management Review 56(4): 1-12.

Ransbotham, S., D. Kiron and P. K. Prentice (2016). "Beyond the Hype: The Hard Work Behind Analytics Success." MIT Sloan Management Review 57(3).

Ringle, C., M. Sarstedt and D. Straub (2012). "A critical look at the use of PLS-SEM in MIS quarterly." MIS Quarterly (MISQ) 36(1).

Ringle, C. M., S. Wende and J.-M. Becker. (2014). "SmartPLS 3." from www.smartpls.com. Roßmann, B., A. Canzaniello, H. von der Gracht and E. Hartmann (2017). "The future and social impact of Big Data Analytics in Supply Chain Management: Results from a Delphi study." Technological Forecasting \& Social Change.

Rothaermel, F. T. and A. M. Hess (2007). "Building Dynamic Capabilities: Innovation Driven by Individual-, Firm-, and Network-Level Effects." Organization Science 18(6): 898-921. 
Ryan, S. D., D. A. Harrison and L. L. Schkade (2002). "Information-technology investment decisions: when do costs and benefits in the social subsystem matter?" Journal of Management Information Systems 19(2): 85-128.

Sabherwal, R. (1999). "The Relationship Between Information System Planning Sophistication and Information System Success: An Empirical Assessment*." Decision Sciences 30(1): 137-167.

Sanders, N. R. and R. Premus (2005). "MODELING THE RELATIONSHIP BETWEEN FIRM IT CAPABILITY, COLLABORATION, AND PERFORMANCE." Journal of Business Logistics 26(1): 1-23.

Sedgwick, P. (2014). "Cross sectional studies: advantages and disadvantages." BMJ : British Medical Journal 348: g2276.

Segars, A. H. and V. Grover (1999). "Profiles of strategic information systems planning." Information Systems Research 10(3): 199-232.

Setia, P. and P. C. Patel (2013). "How information systems help create OM capabilities: Consequents and antecedents of operational absorptive capacity." Journal of Operations Management 31(6): 409-431.

Sharifi, H., H. Ismail and I. Reid (2009). Framework for Developing an Agile Future-Proof Supply Chain. Dispersed Manufacturing Networks: Challenges for Research and Practice. R. Dekkers. London, Springer London: 131-153.

Sharifi, H., H. S. Ismail and I. Reid (2006). "Achieving agility in supply chain through simultaneous "design of" and "design for" supply chain." Journal of Manufacturing Technology Management 17(8): 1078-1098.

Snapp, S. (2017). "Is Big Data the Silver Bullet for Supply-Chain Forecasting?" Foresight: The International Journal of Applied Forecasting(45): 10-14.

Stanko, M. A., F. J. Molina-Castillo and J. L. Munuera-Aleman (2012). "Speed to market for innovative products: blessing or curse?" Journal of Product Innovation Management 29(5): 751-765.

Stone, M. (1974). "Cross-validatory choice and assessment of statistical predictions." Journal of the Royal Statistical Society. Series B (Methodological): 111-147.

Swafford, P. M., S. Ghosh and N. Murthy (2008). "Achieving supply chain agility through IT integration and flexibility." International Journal of Production Economics 116(2): 288-297.

Tay, S. (2016, December 29, 2016). "Supply Chain \& Big Data $\div$ Analytics = Innovation." Supplychain247.com Retrieved May 22, 2019, from https://www.supplychain247.com/article/supply_chain_big_data_analytics_innovation.

Teece, D. and G. Pisano (1994). "The Dynamic Capabilities of Firms: an Introduction." Industrial and Corporate Change 3(3): 537-556.

Teece, D. J. (2012). "Dynamic Capabilities: Routines versus Entrepreneurial Action." Journal of Management Studies 49(8): 1395-1401.

Teece, D. J. (2014). "The foundations of enterprise performance: Dynamic and ordinary capabilities in an (economic) theory of firms." The Academy of Management Perspectives 28(4): 328-352.

Teece, D. J. (2014). "The Foundations of Enterprise Performance: Dynamic and Ordinary Capabilities in an (Economic) Theory of Firms." Academy of Management Perspectives 28(4): 328-352.

Teece, D. J., G. Pisano and A. Shuen (1997). "Dynamic Capabilities and Strategic Management." Strategic Management Journal 18(7): 509-533.

Tenenhaus, M., V. E. Vinzi, Y.-M. Chatelin and C. Lauro (2005). "PLS path modeling." Computational statistics \& data analysis 48(1): 159-205.

Terry Anthony Byrd, D. E. T. (2000). "Measuring the flexibility of information technology infrastructure: Exploratory analysis of a construct." Journal of Management Information Systems 17(1): 167-208. 
Tesch, D., J. J. Jiang and G. Klein (2003). "The impact of information system personnel skill discrepancies on stakeholder satisfaction." Decision Sciences 34(1): 107-129.

Tippins, M. J. and R. S. Sohi (2003). "IT competency and firm performance: is organizational learning a missing link?" Strategic Management Journal 24(8): 745-761.

Tiwari, S., H. M. Wee and Y. Daryanto (2018). "Big data analytics in supply chain management between 2010 and 2016: Insights to industries." Computers \& Industrial Engineering 115: 319-330.

Tsao, Y.-C. (2017). "Managing default risk under trade credit: Who should implement BigData analytics in supply chains?" Transportation Research Part E: Logistics and Transportation Review 106: 276-293.

Venkatesh, V., S. A. Brown and Y. W. Sullivan (2016). "Guidelines for Conducting Mixedmethods Research: An Extension and Illustration." Journal of the Association for Information Systems 17(7): 435-495.

Waller, M. A. and S. E. Fawcett (2013). "Data Science, Predictive Analytics, and Big Data: A Revolution That Will Transform Supply Chain Design and Management." Journal of Business Logistics 34(2): 77-84.

Wamba, S. F., A. Gunasekaran, S. Akter, S. J.-f. Ren, R. Dubey and S. J. Childe (2017). "Big data analytics and firm performance: Effects of dynamic capabilities." Journal of Business Research 70: 356-365.

Wetzels, M., G. Odekerken-Schroder and C. Van Oppen (2009). "Using PLS path modeling for assessing hierarchical construct models: guidelines and empirical illustration." $\underline{\text { MIS }}$ Quarterly 33(1): 177.

Winter, S. G. (2003). "Understanding Dynamic Capabilities." Strategic Management Journal 24(10): 991-995.

Yang, J. (2014). "Supply chain agility: Securing performance for Chinese manufacturers." International Journal of Production Economics 150: 104-113.

Zhang, Z. and H. Sharifi (2000). "A methodology for achieving agility in manufacturing organisations." International Journal of Operations \& Production Management 20(4): 496513.

Zhao, R., Y. Liu, N. Zhang and T. Huang (2017). "An optimization model for green supply chain management by using a big data analytic approach." Journal of Cleaner Production 142(Part 2): 1085-1097. 


\section{Appendix 1: Survey Measures}

\begin{tabular}{|c|c|c|c|c|c|c|}
\hline $\begin{array}{l}\text { 2nd-order } \\
\text { constructs }\end{array}$ & Туре & $\begin{array}{l}\text { 1st-order } \\
\text { constructs }\end{array}$ & Type & $\begin{array}{l}\text { Item } \\
\text { labels }\end{array}$ & Items & Sources \\
\hline \multirow{16}{*}{$\begin{array}{l}\text { Supply chain } \\
\text { analytics } \\
\text { management } \\
\text { capabilities } \\
\text { (SCMAC) }\end{array}$} & \multirow{16}{*}{ 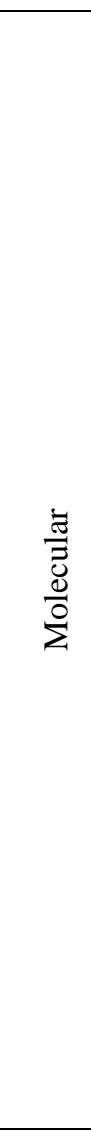 } & \multirow{4}{*}{$\begin{array}{l}\text { Supply chain } \\
\text { planning }\end{array}$} & Reflective & SCPL1 & $\begin{array}{l}\text { We continuously examine the innovative opportunities for the strategic use of supply } \\
\text { chain analytics. }\end{array}$ & \multirow{4}{*}{$\begin{array}{l}\text { (Boynton, Zmud } \\
\text { et al. 1994, } \\
\text { Sabherwal 1999, } \\
\text { Segars and } \\
\text { Grover 1999, } \\
\text { Karimi, Somers } \\
\text { et al. 2001, Kim, } \\
\text { Shin et al. 2012) }\end{array}$} \\
\hline & & & Reflective & SCPL2 & We enforce adequate plans for the introduction and utilization of supply chain analytics. & \\
\hline & & & Reflective & SCPL3 & $\begin{array}{l}\text { We perform supply chain analytics planning processes in systematic and formalized } \\
\text { ways. }\end{array}$ & \\
\hline & & & Reflective & SCPL4 & We frequently adjust supply chain analytics plans to better adapt to changing conditions. & \\
\hline & & \multirow{4}{*}{$\begin{array}{l}\text { Supply chain } \\
\text { investment } \\
\text { decision- } \\
\text { making }\end{array}$} & Reflective & SCID1 & $\begin{array}{l}\text { When we make supply chain analytics investment decisions, we think about and estimate } \\
\text { the effect they will have on the productivity of the employees' work. }\end{array}$ & \multirow{4}{*}{$\begin{array}{l}\text { (Sabherwal 1999, } \\
\text { Ryan, Harrison et } \\
\text { al. 2002, Kim, } \\
\text { Shin et al. 2012) }\end{array}$} \\
\hline & & & Reflective & SCID2 & $\begin{array}{l}\text { When we make supply chain analytics investment decisions, we consider and project } \\
\text { how much these options will help end-users make quicker decisions. }\end{array}$ & \\
\hline & & & Reflective & SCID3 & $\begin{array}{l}\text { When we make supply chain analytics investment decisions, we think about and estimate } \\
\text { the cost of training that end-users will need. }\end{array}$ & \\
\hline & & & Reflective & SCID4 & $\begin{array}{l}\text { When we make supply chain analytics investment decisions, we consider and estimate } \\
\text { the time managers will need to spend overseeing the change. }\end{array}$ & \\
\hline & & \multirow{4}{*}{$\begin{array}{l}\text { Supply chain } \\
\text { coordination }\end{array}$} & Reflective & SCCO1 & $\begin{array}{l}\text { In our organization, supply chain analysts and line people meet frequently to discuss } \\
\text { important issues both formally and informally. }\end{array}$ & \multirow{4}{*}{$\begin{array}{l}\text { (Boynton, Zmud } \\
\text { et al. 1994, } \\
\text { DeSanctis and } \\
\text { Jackson 1994, } \\
\text { Karimi, Somers } \\
\text { et al. 2001, Li, } \\
\text { Jiang et al. 2003, } \\
\text { Kim, Shin et al. } \\
\text { 2012) }\end{array}$} \\
\hline & & & Reflective & SCCO2 & $\begin{array}{l}\text { In our organization, supply chain analysts and line people from various departments } \\
\text { frequently attend cross-functional meetings. }\end{array}$ & \\
\hline & & & Reflective & SCCO3 & $\begin{array}{l}\text { In our organization, supply chain analysts and line people coordinate their efforts } \\
\text { harmoniously. }\end{array}$ & \\
\hline & & & Reflective & SCCO4 & $\begin{array}{l}\text { In our organization, information is widely shared between analysts and line people so } \\
\text { that those who make decisions or perform jobs have access to all available know-how. }\end{array}$ & \\
\hline & & \multirow{4}{*}{$\begin{array}{l}\text { Supply chain } \\
\text { control }\end{array}$} & Reflective & SCCT1 & In our organization, the responsibility for analytics development is clear. & \multirow{4}{*}{$\begin{array}{l}\text { (Karimi, Somers } \\
\text { et al. 2001, Kim, } \\
\text { Shin et al. 2012) }\end{array}$} \\
\hline & & & Reflective & SCCT2 & We are confident that analytics project proposals are properly appraised. & \\
\hline & & & Reflective & SCCT3 & We constantly monitor the performance of the analytics function. & \\
\hline & & & Reflective & SCCT4 & Our analytics department is clear about its performance criteria. & \\
\hline
\end{tabular}




\begin{tabular}{|c|c|c|c|c|c|c|}
\hline \multirow{12}{*}{$\begin{array}{l}\text { Supply chain } \\
\text { analytics } \\
\text { technology } \\
\text { capability } \\
\text { (SCTEC) }\end{array}$} & \multirow{12}{*}{$\frac{\text { 尝 }}{\frac{0}{0}}$} & \multirow{4}{*}{$\begin{array}{l}\text { Supply chain } \\
\text { connectivity }\end{array}$} & Reflective & SCCN1 & $\begin{array}{l}\text { Compared to rivals within our industry, our organization has the foremost available } \\
\text { analytics systems. }\end{array}$ & \multirow[t]{4}{*}{$\begin{array}{l}\text { (Duncan 1995, Terry } \\
\text { Anthony Byrd 2000, } \\
\text { Kim, Shin et al. 2012) }\end{array}$} \\
\hline & & & Reflective & SCCN2 & All remote branchs and mobile offices are connected to the central office for analytics. & \\
\hline & & & Reflective & SCCN3 & $\begin{array}{l}\text { Our organization utilizes open system network mechanisms to boost analytics } \\
\text { connectivity. }\end{array}$ & \\
\hline & & & Reflective & SCCN4 & $\begin{array}{l}\text { There are no identifiable communications bottlenecks within our organization when } \\
\text { sharing analytics insights. }\end{array}$ & \\
\hline & & \multirow{4}{*}{$\begin{array}{l}\text { Supply chain } \\
\text { Compatibility }\end{array}$} & Reflective & SCCM1 & $\begin{array}{l}\text { Software applications can be easily transported and used across multiple analytics } \\
\text { platforms. }\end{array}$ & \multirow{4}{*}{$\begin{array}{l}\text { (Duncan 1995, Terry } \\
\text { Anthony Byrd 2000, } \\
\text { Kim, Shin et al. 2012) }\end{array}$} \\
\hline & & & Reflective & SCCM2 & Our user interfaces provide transparent access to all platforms and applications. & \\
\hline & & & Reflective & SCCM3 & $\begin{array}{l}\text { Analytics-driven information is shared seamlessly across our organization, regardless } \\
\text { of the location. }\end{array}$ & \\
\hline & & & Reflective & SCCM4 & $\begin{array}{l}\text { Our organization provides multiple analytics interfaces or entry points for external } \\
\text { end-users. }\end{array}$ & \\
\hline & & \multirow{4}{*}{$\begin{array}{l}\text { Supply chain } \\
\text { Modularity }\end{array}$} & Reflective & SCMD1 & Reusable software modules are widely used in new analytics model development. & \multirow{4}{*}{$\begin{array}{l}\text { (Duncan 1995, } \\
\text { Broadbent, Weill et al. } \\
\text { 1999, Terry Anthony } \\
\text { Byrd 2000, Kim, Shin et } \\
\text { al. 2012) }\end{array}$} \\
\hline & & & Reflective & SCMD2 & End-users utilize object-oriented tools to create their own analytics applications. & \\
\hline & & & Reflective & SCMD3 & $\begin{array}{l}\text { Object-oriented technologies are utilized to minimize the development time for new } \\
\text { analytics applications. }\end{array}$ & \\
\hline & & & Reflective & SCMD4 & Applications can be adapted to meet a variety of needs during analytics tasks. & \\
\hline \multirow{11}{*}{$\begin{array}{l}\text { Supply chain } \\
\text { analytics } \\
\text { talent } \\
\text { capability } \\
\text { (SCTLC) }\end{array}$} & \multirow{11}{*}{ 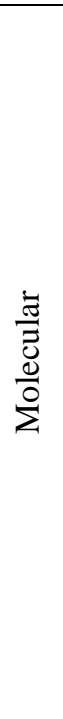 } & \multirow{4}{*}{$\begin{array}{l}\text { Supply chain } \\
\text { Technical } \\
\text { Knowledge }\end{array}$} & Reflective & SCTK1 & Our analytics personnel are very capable in terms of programming skills. & \multirow{4}{*}{$\begin{array}{l}\text { (Boar 1995, Lee, Trauth } \\
\text { et al. 1995, Broadbent, } \\
\text { Weill et al. 1999, Terry } \\
\text { Anthony Byrd 2000, } \\
\text { Kim, Shin et al. 2012) }\end{array}$} \\
\hline & & & Reflective & SCTK2 & Our analytics personnel are very capable in terms of managing project life cycles. & \\
\hline & & & Reflective & SCTK3 & $\begin{array}{l}\text { Our analytics personnel are very capable in the areas of data and network management } \\
\text { and maintenance. }\end{array}$ & \\
\hline & & & Reflective & SCTK4 & $\begin{array}{l}\text { Our analytics personnel create very capable decision support systems driven by } \\
\text { analytics. }\end{array}$ & \\
\hline & & \multirow{4}{*}{$\begin{array}{l}\text { Supply chain } \\
\text { Technology } \\
\text { Management } \\
\text { Knowledge }\end{array}$} & Reflective & SCTM1 & Our analytics personnel show superior understanding of technological trends. & \multirow{4}{*}{$\begin{array}{l}\text { (Terry Anthony Byrd } \\
\text { 2000, Tippins and Sohi } \\
\text { 2003, Kim, Shin et al. } \\
\text { 2012) }\end{array}$} \\
\hline & & & Reflective & SCTM2 & Our analytics personnel show superior ability to learn new technologies. & \\
\hline & & & Reflective & SCTM3 & $\begin{array}{l}\text { Our analytics personnel are very knowledgeable about the critical factors for the } \\
\text { success of our organization. }\end{array}$ & \\
\hline & & & Reflective & SCTM4 & $\begin{array}{l}\text { Our analytics personnel are very knowledgeable about the role of big data analytics as } \\
\text { a means, not an end. }\end{array}$ & \\
\hline & & \multirow{3}{*}{$\begin{array}{l}\text { Supply chain } \\
\text { Business } \\
\text { Knowledge }\end{array}$} & Reflective & SCBK1 & $\begin{array}{l}\text { Our analytics personnel understand our organization’s policies and plans at a very } \\
\text { high level. }\end{array}$ & \multirow{3}{*}{$\begin{array}{l}\text { (Duncan 1995, Terry } \\
\text { Anthony Byrd 2000, } \\
\text { Tesch, Jiang et al. 2003, } \\
\text { Kim, Shin et al. 2012) }\end{array}$} \\
\hline & & & Reflective & SCBK2 & $\begin{array}{l}\text { Our analytics personnel are very capable in interpreting business problems and } \\
\text { developing appropriate technical solutions. }\end{array}$ & \\
\hline & & & Reflective & SCBK3 & Our analytics personnel are very knowledgeable about business functions. & \\
\hline
\end{tabular}




\begin{tabular}{|c|c|c|c|c|c|c|}
\hline & & & Reflective & SCBK4 & Our analytics personnel are very knowledgeable about the business environment. & \\
\hline & & \multirow{4}{*}{$\begin{array}{l}\text { Supply chain } \\
\text { Relational } \\
\text { Knowledge }\end{array}$} & Reflective & SCRK1 & $\begin{array}{l}\text { Our analytics personnel are very capable in terms of planning, organizing, and leading } \\
\text { projects. }\end{array}$ & \multirow{4}{*}{$\begin{array}{l}\text { (Boar 1995, Duncan } \\
\text { 1995, Lee, Trauth et al. } \\
\text { 1995, Terry Anthony } \\
\text { Byrd 2000, Jiang, Klein } \\
\text { et al. 2003, Kim, Shin et } \\
\text { al. 2012) }\end{array}$} \\
\hline & & & Reflective & SCRK2 & $\begin{array}{l}\text { Our analytics personnel are very capable in terms of planning and executing work in a } \\
\text { collective environment. }\end{array}$ & \\
\hline & & & Reflective & SCRK3 & Our analytics personnel are very capable in terms of teaching others. & \\
\hline & & & Reflective & SCRK4 & $\begin{array}{l}\text { Our analytics personnel work closely with customers and maintain productive } \\
\text { user/client relationships. }\end{array}$ & \\
\hline \multirow{5}{*}{$\begin{array}{l}\text { Supply chain } \\
\text { agility }\end{array}$} & \multirow{5}{*}{ NA } & \multirow{5}{*}{ NA } & Reflective & AGIL1 & Our organization works hard to promote the flow of information with its suppliers & \multirow[t]{5}{*}{ (Setia and Patel 2013) } \\
\hline & & & Reflective & AGIL2 & Our organization works hard to develop collaborative relationships with suppliers. & \\
\hline & & & Reflective & AGIL3 & $\begin{array}{l}\text { Our organization builds inventory buffers by maintaining a stockpile of } \\
\text { inexpensive but key components. }\end{array}$ & \\
\hline & & & Reflective & AGIL4 & $\begin{array}{l}\text { Our organization draws up contingency plans and develops crisis management } \\
\text { teams. }\end{array}$ & \\
\hline & & & Reflective & AGIL5 & Our organization has a dependable logistics system or partner. & \\
\hline \multirow{5}{*}{$\begin{array}{l}\text { Firm } \\
\text { Performance } \\
\text { (FPER) }\end{array}$} & \multirow{5}{*}{ NA } & \multirow{5}{*}{ NA } & \multirow{5}{*}{ Reflective } & \multicolumn{2}{|c|}{ Using supply chain analytics improved ___ during the last 3 years relative to competitors: } & \multirow[t]{5}{*}{$\begin{array}{l}\text { (Tippins and Sohi } \\
\text { 2003) }\end{array}$} \\
\hline & & & & FPER1 & Customer retention & \\
\hline & & & & FPER2 & Sales growth & \\
\hline & & & & FPER3 & Profitability & \\
\hline & & & & FPER4 & __ Return on investment & \\
\hline
\end{tabular}

